\title{
SYNTHESIS OF ZnO:N THIN FILMS BY REACTIVE DC MAGNETRON SPUTTERING
}

\author{
S. Burinskas 目, J. Dudonis 国, D. Milčius 国, M. Karaliūnas ब, and E. Kuokštis \\ ${ }^{a}$ Department of Physics, Kaunas University of Technology, Studentu 50, LT-51368 Kaunas, Lithuania \\ E-mail: saulius.burinskas@stud.ktu.lt \\ ${ }^{\mathrm{b}}$ Centre for Hydrogen Energy Technologies, Lithuania Energy Institute, Breslaujos 3, LT-44403 Kaunas, Lithuania \\ E-mail: milcius@mail.lei.lt \\ ${ }^{\mathrm{c}}$ Semiconductor Physics Department and Institute of Applied Research, Vilnius University, Sauletekio 9, LT-10222 Vilnius, \\ Lithuania \\ E-mail: mindaugas.karaliunas@ff.vu.lt
}

Received 17 March 2010; revised 12 July 2010; accepted 16 September 2010

\begin{abstract}
Structural, electrical, and optical properties of nitrogen doped zinc oxide (ZnO:N) thin films deposited by direct current magnetron sputtering are analysed in this work. Nitrogen doping allows creation of $p$-type semiconducting $\mathrm{ZnO}$ thin films for their most important application as light emitting diodes. The scanning electron microscope images of sample cross-section show dense structure with columnar growth features. The X-ray diffraction patterns indicate semi-amorphous structure, explaining very low photoluminescence intensity. Optical transmittance measurements reveal significant changes in optical properties upon different amount of nitrogen doping. The resistance measurements in $30-90^{\circ} \mathrm{C}$ temperature range of $\mathrm{ZnO}: \mathrm{N}$ thin films demonstrate similar to semiconductor behaviour and show resistance change up to $50 \%$.
\end{abstract}

Keywords: reactive magnetron sputtering, nitrogen doped zinc oxide, $p$-type $\mathrm{ZnO}$ thin films, LED

PACS: 68.55.-a, 73.61.-r, 78.20.-e, 81.15.Cd

\section{Introduction}

$\mathrm{ZnO}$ thin films and nanostructures have been investigated for a long time as a very promising material for piezoelectric [1], gas sensing [2], transparent conducting oxides [3], for spintronics [4], ultra-violet (UV) light-emitting diodes (LEDs) [5], and other applications. The main reasons why $\mathrm{ZnO}$ is suitable for LEDs application are the wide band gap of $3.37 \mathrm{eV}$ at room temperature and an extremely large free exciton binding energy of $60 \mathrm{meV}$, which allows excitonic emission even at room temperature and above in near UV spectral region $[5,6]$. The availability of large-area $\mathrm{ZnO}$ substrates and the possibility of relatively low temperature epitaxial growth make it superior to $\mathrm{ZnO}$ main competitors [7]. Moreover, $\mathrm{ZnO}$ is a material of great natural abundance and friendly to environment.

The synthesis of $n$-type $\mathrm{ZnO}$ of low resistivity by doping with $\mathrm{Al}$ was already demonstrated by many authors [2, 3]. Unfortunately the lack of viable $p$-type doped $\mathrm{ZnO}$ prevents development of LEDs based on $p-n$ homojunction despite many studies of $\mathrm{ZnO}$ for LEDs application [6]. As-grown $\mathrm{ZnO}$ is usually $n$-type whether by design or by accident. The experiments and theory have shown that oxygen vacancies and other native point defects are likely the predominant cause of unintentional $n$-type conductivity in $\mathrm{ZnO}$ owing to the impurities such as $\mathrm{Al}$ and $\mathrm{H}$. Therefore the key challenge is to introduce the sufficient concentrations of acceptors without being overwhelmed by compensating donors [8]. Till present the nitrogen is found to be the most promising candidate for the acceptor doping, because of its ionic radii similarity to oxygen [5]. The $p$-type $\mathrm{ZnO}: \mathrm{N}$ synthesis was performed by various techniques including metal-organic chemical vapour deposition [9], radio-frequency [10] and directcurrent [11, 12] magnetron sputtering, pulsed laser deposition [13], and other. The most important parameters in evaluating the performance of $p$-type doping process are the acceptor activation energy $E_{\mathrm{A}}$, hole mobility $\mu_{p}$, and concentration $n_{p}$. The $\mu_{p}$ and $n_{p}$ cannot be accurately determined in $p$-type $\mathrm{ZnO}$ samples, because the Hall voltage is very small due to small $\mu_{p}$ (often $<1 \mathrm{~cm}^{2} /(\mathrm{V} \mathrm{s})$ ) [5]. Thus, the resistivity becomes the most important factor for comparison of $p$-type $\mathrm{ZnO}$ properties in literature. The resistivity of $\mathrm{N}$ doped $\mathrm{ZnO}$ 
is reported to be varying from 1 to $150 \Omega \mathrm{cm}$ [5]. The $E_{\mathrm{A}}$ values determined by photoluminescence (PL) measurements also vary over a wide range from 165 to $248 \mathrm{meV}$, while the values determined by temperaturedependent Hall effect ( $T$-Hall) measurements are considerably lower than the former and vary over the range from 75 to $100 \mathrm{meV}$ [13]. The discrepancy between activation energies found by $T$-Hall and PL is explained by carrier screening effect [14]. However, the lack of reliable information motivates further research, since the values of the most $p$-type $\mathrm{ZnO}: \mathrm{N}$ characteristics show broad distribution [15] and most likely strongly depend on substrate and deposition technique.

There are also some reports in the literature about reversible $p$-type conductivity in $\mathrm{ZnO}: \mathrm{N}$ that may change to $n$-type after repeated measurements in the dark and become $p$-type again after exposure to sunlight [15]. This effect probably means that acceptors become negatively ionized in the absence of light excitation due to large concentration of compensating donors such as group-III impurities. Therefore reports of successful $p$-type $\mathrm{ZnO}$ synthesis are often viewed with skepticism because of the $p$-type reliability problems [8].

The reactive magnetron sputtering is widely used for deposition of dense metal compound thin films. The leaked plasma of unbalanced direct current (DC) magnetron discharge creates a self-bias on the surface of the insulating or isolated film surface [16]. The substrate can become self-biased up to $-30 \mathrm{~V}$, thus high ion current can be extracted from plasma without the need to bias the substrate externally [17]. As a result, unlike in the other ion-plating processes, the ion-to-atom arrival ratio at the substrate remains constant with increasing deposition rate, and that helps to achieve dense film structure [18].

The provision of enough atomic nitrogen with high chemical reactivity is the general issue in the growth of zinc oxynitride. In the case of chemical vapour deposition method for the growth of nitride films, $\mathrm{NH}_{3}$ gas is preferentially used as a nitrogen source because $\mathrm{NH}_{3}$ gas easily decomposes at a lower temperature than $\mathrm{N}_{2}$ molecules with high thermal stability. As this method requires high substrate temperature of $410^{\circ} \mathrm{C}$ for the reaction, it is difficult to control the film thickness due to the uncontrolled evaporation of the metallic zinc film. On the contrary, plasma methods make the low temperature formation of various nitride films possible due to the provision of active nitrogen species from plasma [19].

There is not enough information and reliable method for deposition of nitrogen doped $\mathrm{ZnO}$ thin films. There- fore the purpose of the present investigation is to analyse the structural, electrical, and optical properties of $\mathrm{ZnO}: \mathrm{N}$ thin films deposited by DC magnetron sputtering.

\section{Experimental procedure}

Nitrogen doped $\mathrm{ZnO}$ thin films were deposited by DC unbalanced magnetron sputtering on the Si substrates for X-ray diffraction (XRD) and scanning electron microscope (SEM) analysis and soda-lime glass substrates for optical and electrical characterization.

The substrates were ultrasonically cleaned in pure

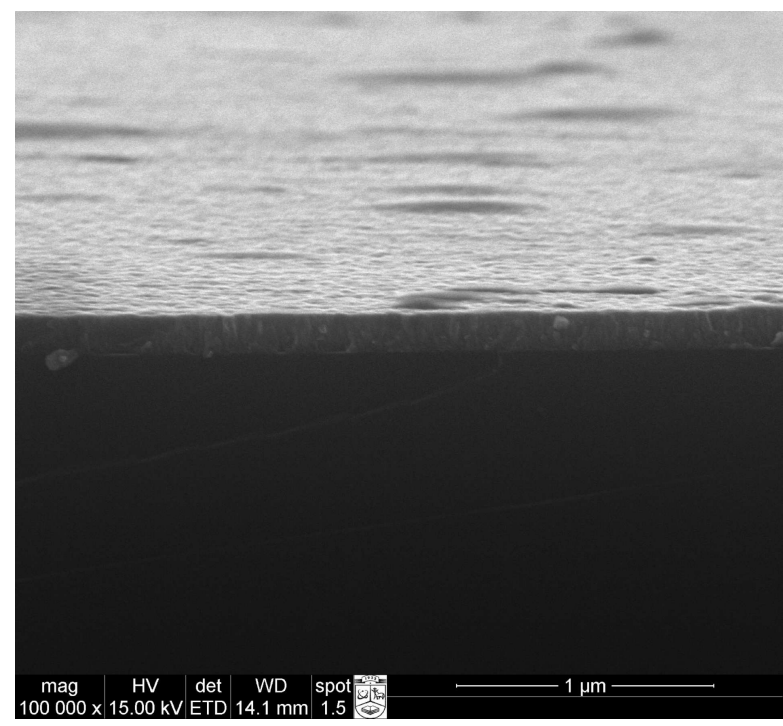

Fig. 1. The cross-section SEM image of $\mathrm{ZnO}: \mathrm{N}$ thin film with magnification $100000\left(p_{\mathrm{O}_{2}}=1.0 \cdot 10^{-2} \mathrm{~Pa}\right)$.

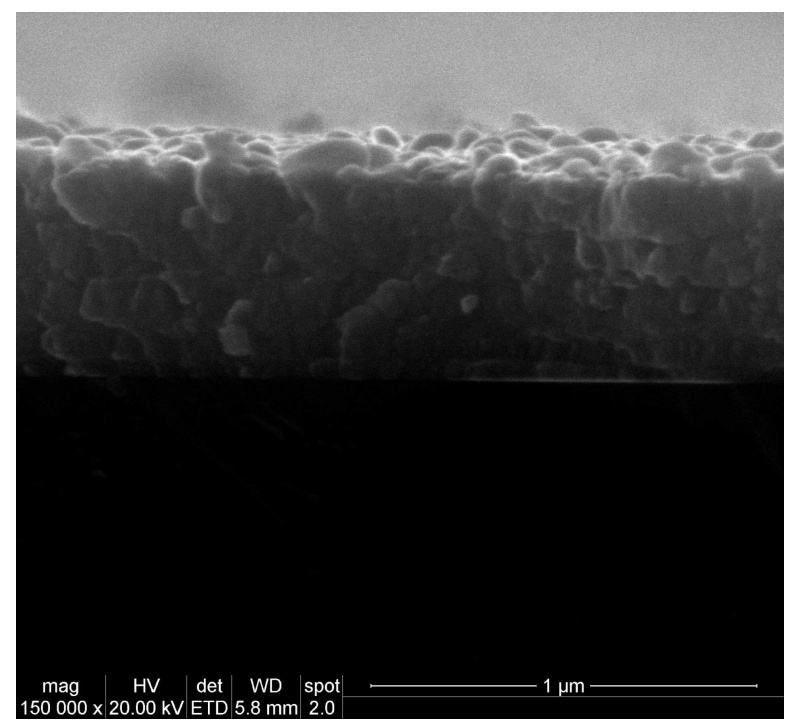

Fig. 2. The cross-section SEM image of $\mathrm{ZnO}: \mathrm{N}$ thin film with magnification $150000\left(p_{\mathrm{O}_{2}}=2.2 \cdot 10^{-2} \mathrm{~Pa}\right)$. 
acetone and rinsed in distilled water before the deposition. The vacuum chamber was evacuated by rotary and diffusion pumps to the pressure of $7 \cdot 10^{-3} \mathrm{~Pa}$. Partial pressure of argon was kept constant at $1.5 \cdot 10^{-2} \mathrm{~Pa}$. Working pressure was kept constant at $2.0 \cdot 10^{-1} \mathrm{~Pa}$ by adjusting nitrogen and oxygen gas flows. Substrate holder was heated to $230^{\circ} \mathrm{C}$ temperature before deposition. The substrate holder was moved in circular trajectory at $7 \mathrm{~cm}$ distance over the planar magnetron target during the deposition. Deposition was performed with a constant discharge current density of $8 \mathrm{~mA} / \mathrm{cm}^{2}$. The current density from plasma of the unbalanced magnetron to substrate was around $-3.5 \mathrm{~mA} / \mathrm{cm}^{2}$. Samples were kept in vacuum for $20 \mathrm{~min}$ after deposition for cooling down.

The crystallographic structure of thin films was investigated by XRD studies using Bruker D8 Discover diffractometer with the monochromatic $\mathrm{Cu} \mathrm{K} \alpha$ radiation $(\lambda=0.15418 \mathrm{~nm})$.

The morphology of cross-section of the layers was investigated with the SEM FEI Quanta 200F in the secondary electron mode.

Strip shaped aluminium contacts for resistance measurements were evaporated on the top of the film and the linearity of $V-I$ characteristic was checked for confirmation of ohmic contact behaviour. Resistivity was calculated using the resistance of the square region between $\mathrm{Al}$ contacts.

Optical characterization of thin films on glass substrate was made by UV-VIS spectrophotometer Spec- tronic GENESYS 8. Forbidden energy band gap $E_{\mathrm{g}}$ was determined from transmittance spectra using Tauc's relationship $(\alpha h \nu)^{m}=B\left(h \nu-E_{\mathrm{g}}\right)$ and by extrapolating this dependence to $h \nu$ axis (light quantum energy) [20]. Absorption coefficient $\alpha\left(\mathrm{cm}^{-1}\right)$ was calculated using transmittance coefficients of film on glass substrate and substrate without a film. Coefficient $m=1 / 2$ is used for indirect transitions, $m=2$ or $m=3 / 2$ are used for direct transitions. Linear correlation analysis was made in order to choose the most suitable mode.

PL measurements were held at room temperature and $8 \mathrm{~K}$ temperature using the 4th harmonic of YAG:Nd laser $\left(h \nu_{\mathrm{exc}}=4.66 \mathrm{eV}\right)$ in back-scattering configuration. Laser beam was focused on the sample surface to the round spot of $2 r=1 \mathrm{~mm}$ in diameter. Vertically polarized PL signal was collected to the double grating monochromator with the focal length of $0.6 \mathrm{~m}$ and measured using a photomultiplier tube.

\section{Experimental results and discussion}

The SEM images of $\mathrm{ZnO}: \mathrm{N}$ thin films cross-section are shown in Figs. 1 and 2. It can be seen that the layers do not have clear features of expected columnar structure and are quite dense and completely continuous. The disagreement of morphology results with the results of other authors $[1,8]$ cannot be explained only by $\mathrm{ZnO}$ sample doping or movement of substrate holder, which was used during the film deposition in this work.

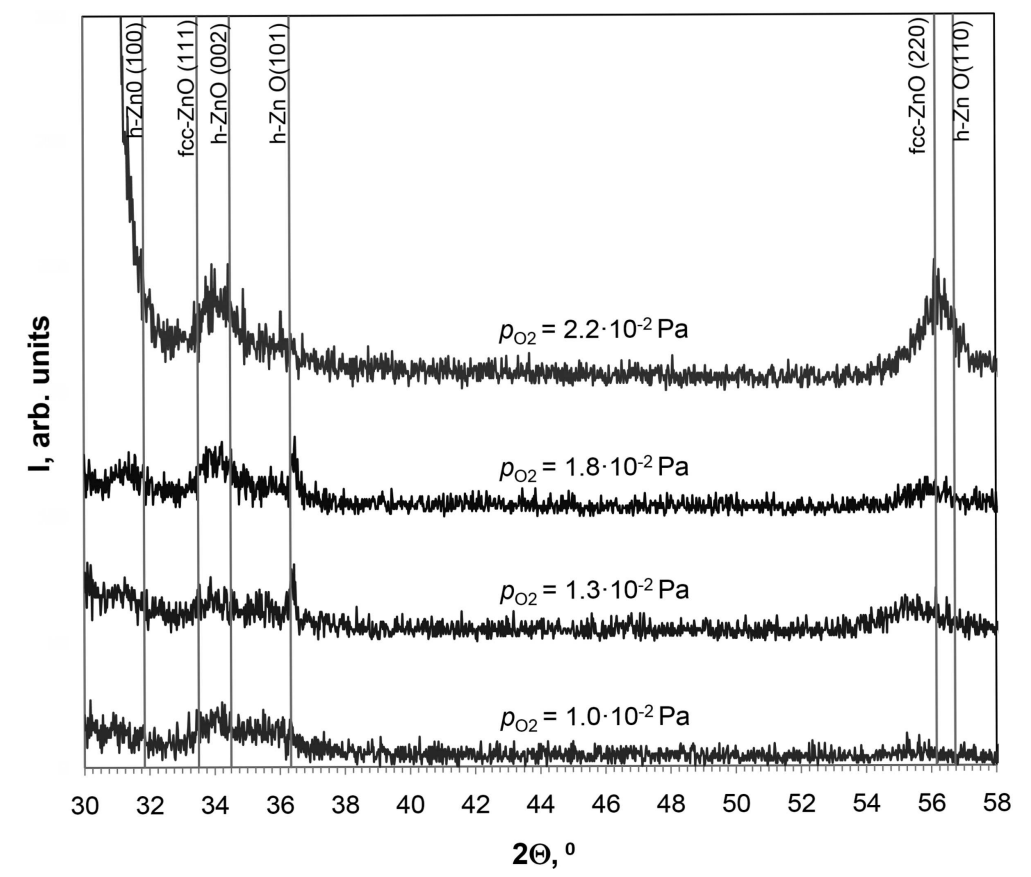

Fig. 3. XRD pattern of $\mathrm{ZnO}: \mathrm{N}$ thin films produced on the Si substrates with different oxygen partial pressure $p_{\mathrm{O}_{2}}$. 


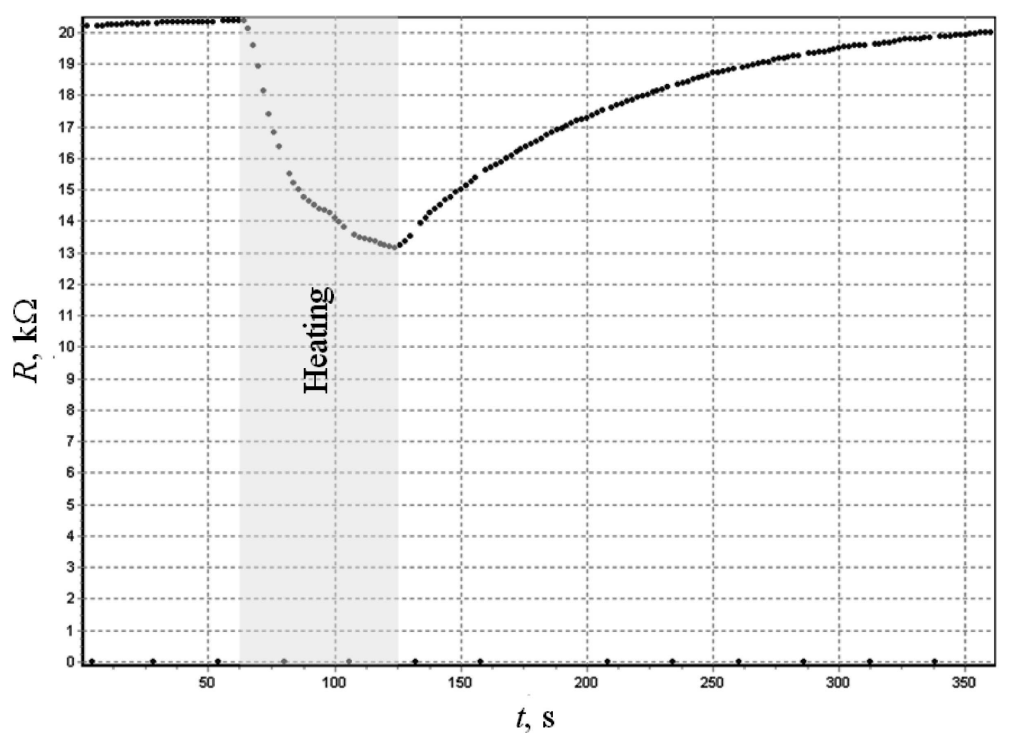

Fig. 4. Results of $\mathrm{ZnO}: \mathrm{N}\left(p_{\mathrm{O}_{2}}=1.0 \cdot 10^{-2} \mathrm{~Pa}\right)$ film resistance measurement during heating and cooling. $300^{\circ} \mathrm{C}$ temperature air flow was applied for 1 minute. Total measurement time is 6 minutes.

The measurements of layer thicknesses from SEM images were 151 and $536 \mathrm{~nm}$ for the samples deposited with $p_{\mathrm{O}_{2}}=1.0 \cdot 10^{-2} \mathrm{~Pa}$ and $p_{\mathrm{O}_{2}}=2.2 \cdot 10^{-2} \mathrm{~Pa}$ oxygen partial pressure, respectively.

Figure 3 shows results of XRD analysis of $\mathrm{ZnO}: \mathrm{N}$ thin films produced on Si substrates. The broad and low intensity diffraction peaks indicate very poor crystal structure of the films, as can be expected for the low temperature growth on the non-lattice-matched substrate. The peaks that can be found in XRD spectra most likely belong to hexagonal $\mathrm{ZnO}(\mathrm{h}-\mathrm{ZnO})$ structure (wurtzite type), which is mostly observed in sputter deposited $\mathrm{ZnO}$ thin films and well agrees with other authors [11]. Also the h-ZnO (002) and h-ZnO (110) peak shift and broadening can be attributed to overlapping with the peaks of metastable face centred cubic (fcc$\mathrm{ZnO}$ ) structure (zincblende type). Such case should be expected only if epitaxial films are grown on the substrates with zincblende structure [21] or under oxygen rich conditions [22].

The degradation of crystal structure upon decrease of partial oxygen pressure can be expected since the cubic anti-bixbyite type structure of $\mathrm{Zn}_{3} \mathrm{~N}_{2}$ [23] has the different lattice spacing and atom arrangement compared to the wurtzite type $\mathrm{ZnO}$ structure.

The resistance dependences on temperature and illumination were measured for $\mathrm{ZnO}: \mathrm{N}$ film deposited on glass substrate with $\mathrm{Al}$ contacts on the top of the film in order to obtain evidence for semiconducting behaviour of electrical properties of thin films that were synthesized in this work. Only the dependences on temperature and heating-cooling time are presented in this

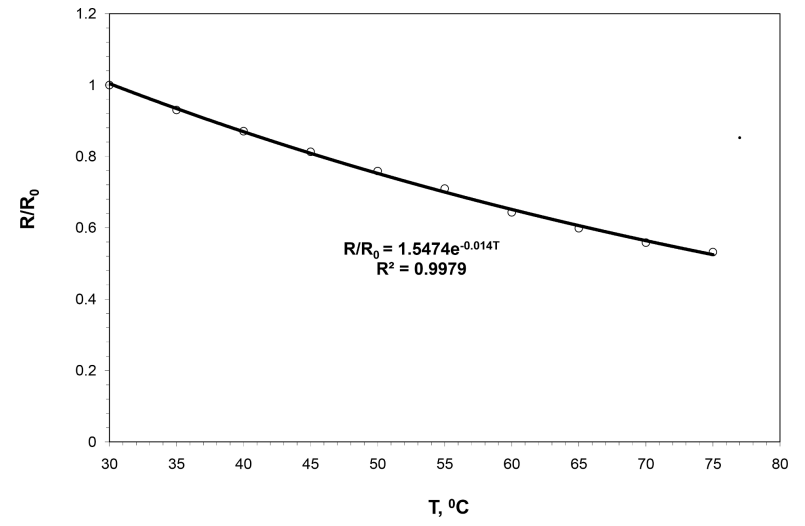

Fig. 5. Results of resistance measurement during heating $\mathrm{ZnO}: \mathrm{N}$ $\left(p_{\mathrm{O}_{2}}=1.0 \cdot 10^{-2} \mathrm{~Pa}\right)$ film in temperatures from 30 to $90^{\circ} \mathrm{C}$. Exponential approximation results including correlation coefficient $R^{2}$ are indicated in the figure.

work, since the resistance changes on high intensity illumination were more likely dependent on heating with the infrared part of radiation. The inability to measure photoconductivity can be attributed to large defect concentration in the film and fast recombination of the photo-excited carriers.

As can be seen in Figs. 4 and 5, the resistance slowly drops to around $50 \%$ of primary value upon heating the sample and slowly reaches the primary value upon cooling. The large (exponential) drop of the resistivity is a typical phenomenon of semiconducting materials. The smallest resistivity of $0.61 \Omega \mathrm{cm}$ was obtained for the film deposited with $p_{\mathrm{O}_{2}}=1.0 \cdot 10^{-2} \mathrm{~Pa}$. The largest measurable resistivity of $695.4 \Omega \mathrm{cm}$ was obtained for the film deposited with $p_{\mathrm{O}_{2}}=1.8 \cdot 10^{-2} \mathrm{~Pa}$. These values well agree with some works of other authors [6]. 


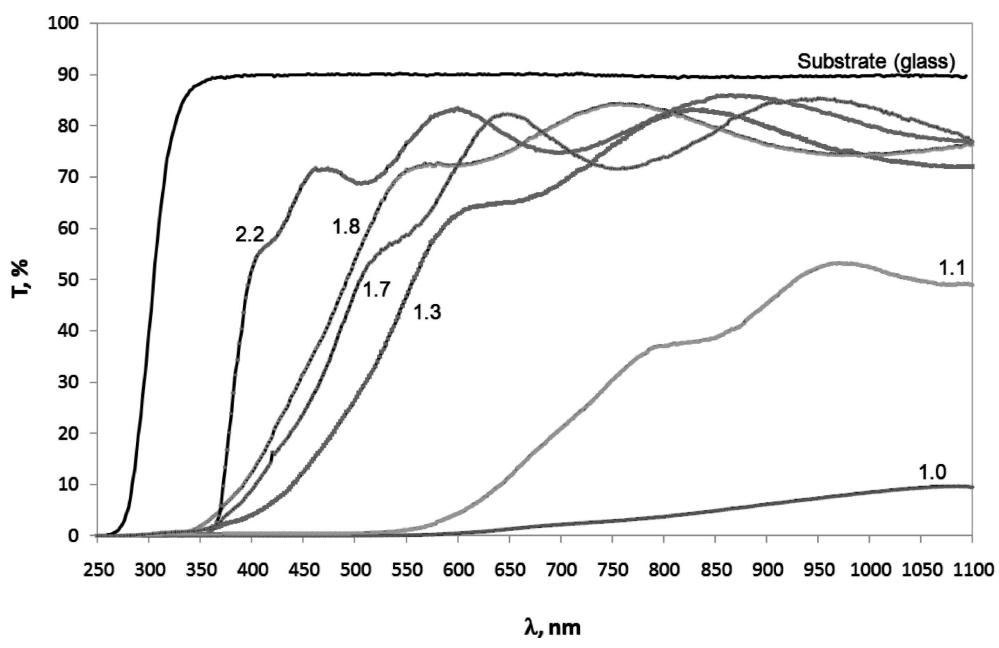

Fig. 6. Optical transmittance spectrum of films produced on the soda-lime glass substrates. Numbers indicate oxygen partial pressure $p_{\mathrm{O}_{2}}$ (in $10^{-2} \mathrm{~Pa}$ ).

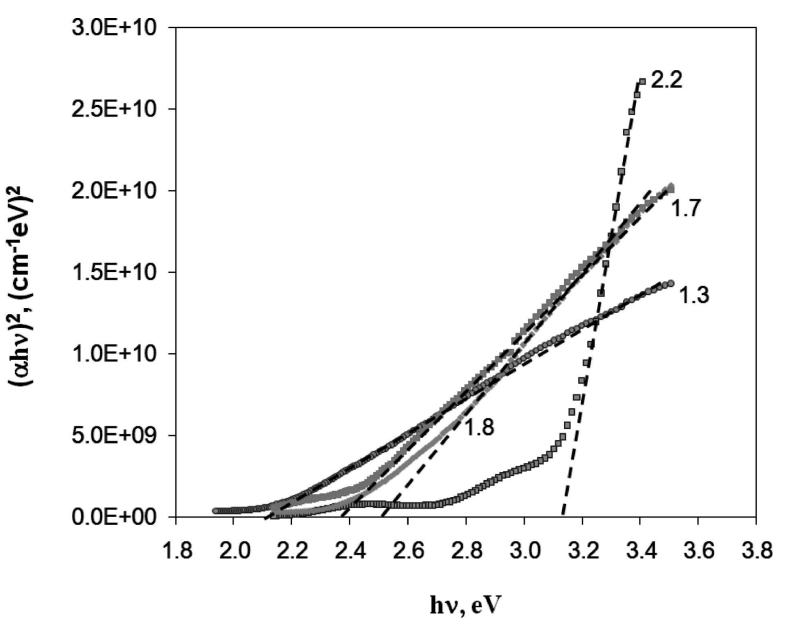

Fig. 7. Tauc's plot for ZnO:N films deposited with various oxygen partial pressures $p_{\mathrm{O}_{2}}$ (in $10^{-2} \mathrm{~Pa}$ ).

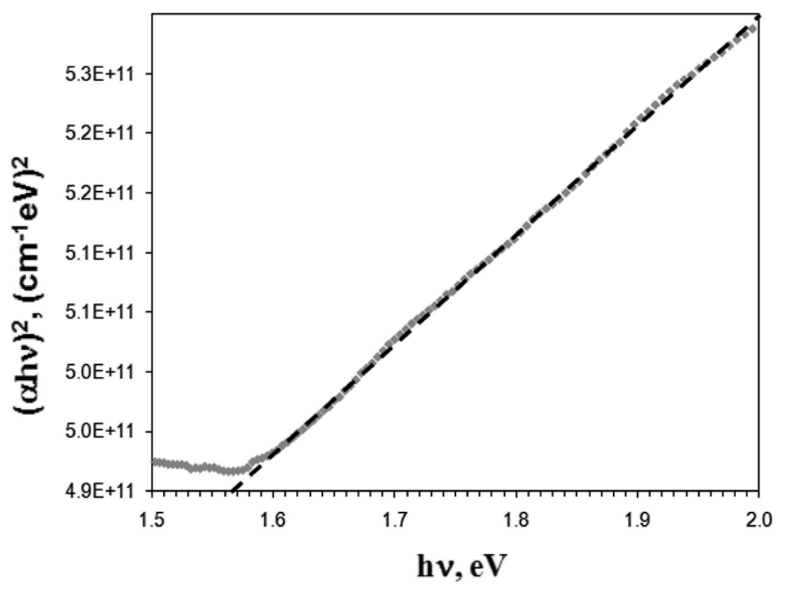

Fig. 8. Tauc's plot for $\mathrm{ZnO}: \mathrm{N}$ films deposited with oxygen partial pressure $p_{\mathrm{O}_{2}}=1.2 \cdot 10^{-2} \mathrm{~Pa}$.

Optical transmittance measurement has shown the shift of the absorption edge to the longer wavelength

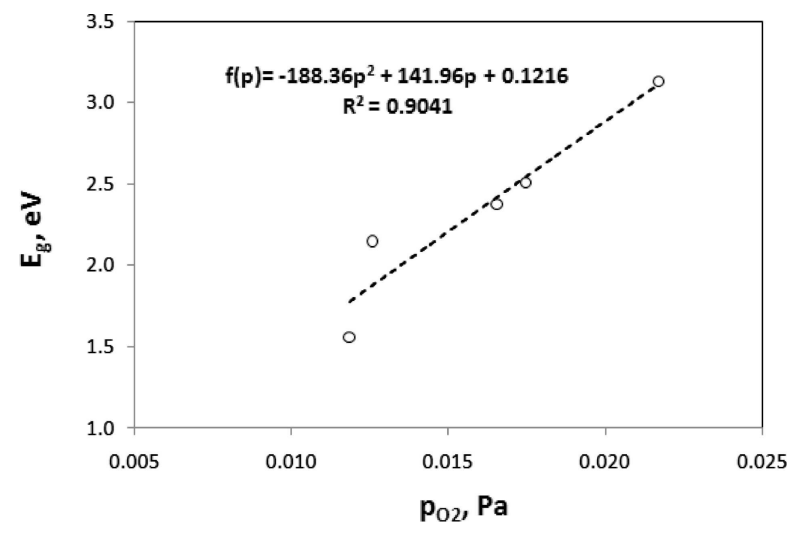

Fig. 9. ZnO:N band gap dependency on oxygen partial pressure $p_{\mathrm{O}_{2}}$ during deposition. Polynomial approximation results including correlation coefficient $R^{2}$ are indicated in the figure.

side (Fig. 6). This phenomenon partially confirms that the samples have been doped with nitrogen. The band gap determination from Tauc's relationship for direct transitions (Figs. 7 and 8 ) has shown that nitrogen doping leads to band gap decrease from 3.12 to $1.56 \mathrm{eV}$ (Fig. 9). Band gap variation from 3.4 to $2.9 \mathrm{eV}$ upon $\mathrm{N}$ doping is a well known phenomenon that can be attributed to $\mathrm{N}$ incorporation into $\mathrm{ZnO}$ lattice and formation of shallow acceptors [24]. However, band gap values lower than $2.9 \mathrm{eV}$ could rather indicate formation of mixture of polycrystalline and amorphous $\mathrm{ZnO}$. It is well known that in semiconductors, especially in amorphous ones, the distribution of electronic states in conduction and valence band do not abruptly terminates at the band edges. Instead of that, some electronic states, so called tail states, encroach into the band gap region [20]. The formation of an amorphous $\mathrm{Zn}_{3} \mathrm{~N}_{2}$ with the band gap of $1.21 \mathrm{eV}$ and the absorption edge below the 


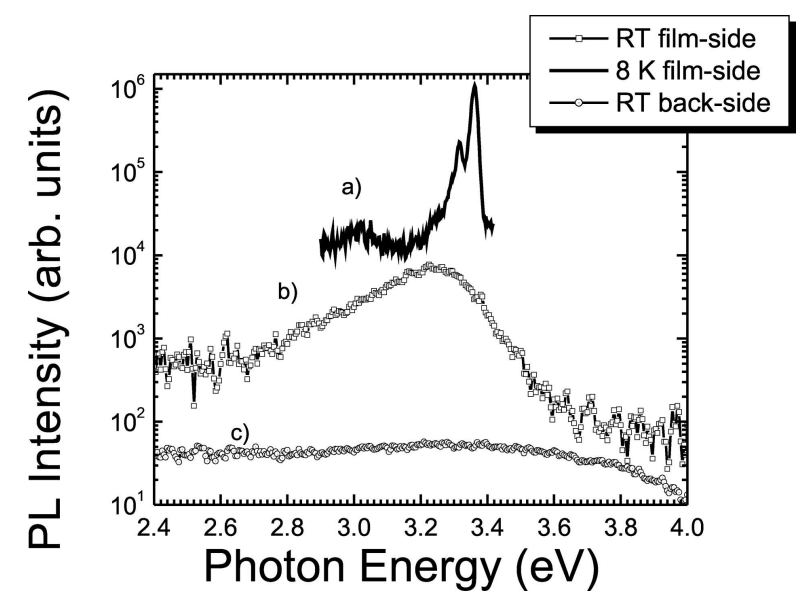

Fig. 10. PL spectra of ZnO:N film on the glass substrate at (a) $8 \mathrm{~K}$ and (b) room temperature; (c) curve demonstrates PL spectrum from back-side of the sample. Spectra are arbitrary shifted for eye convenience.

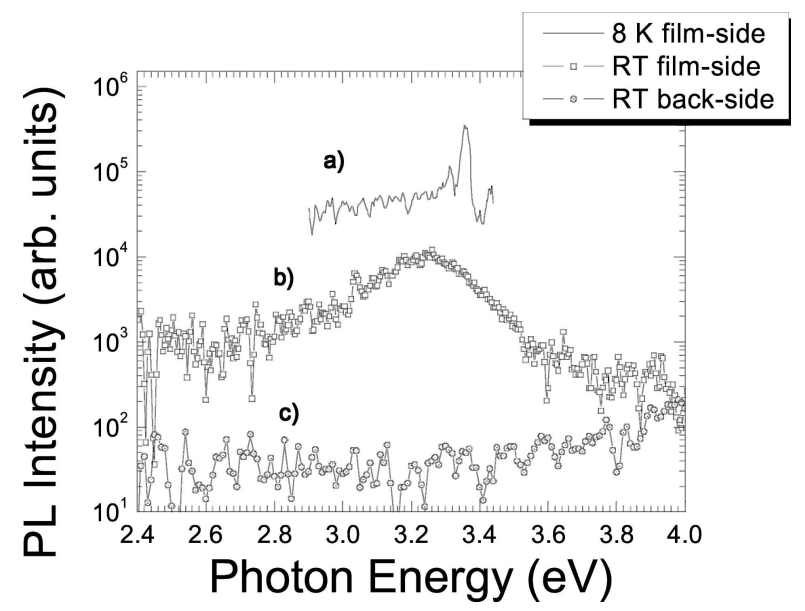

Fig. 11. PL spectra of ZnO:N film on the Si substrate at (a) $8 \mathrm{~K}$ and (b) room temperature; (c) curve demonstrates PL spectrum from back-side of the sample. Spectra are arbitrary shifted for eye convenience.

wavelength of $500 \mathrm{~nm}$ [23] is also possible during deposition.

The decrease of transparency maximum upon increased $\mathrm{N}_{2}$ doping $\left(p_{\mathrm{O}_{2}}<1.3 \cdot 10^{-2} \mathrm{~Pa}\right)$ could also indicate increased roughness and degradation of crystalline structure, which leads to increased density of scattering centres. The formation of $\mathrm{Zn}$ metal clusters (absorption and scattering centres) in the $\mathrm{ZnO}: \mathrm{N}$ film matrix could also occur, since the decrease of oxygen flow can increase the flow of sputtered $\mathrm{Zn}$ atoms due to lower target surface poisoning with oxide layer.

Two samples were prepared for PL measurements: one of them consists of the film grown on glass substrate, while the other sample has the film grown on Si substrate under the same partial oxygen pressure, namely $1.7 \cdot 10^{-2} \mathrm{~Pa}$. The typical PL spectra are shown
$D^{0} \mathrm{X}$

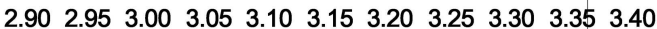

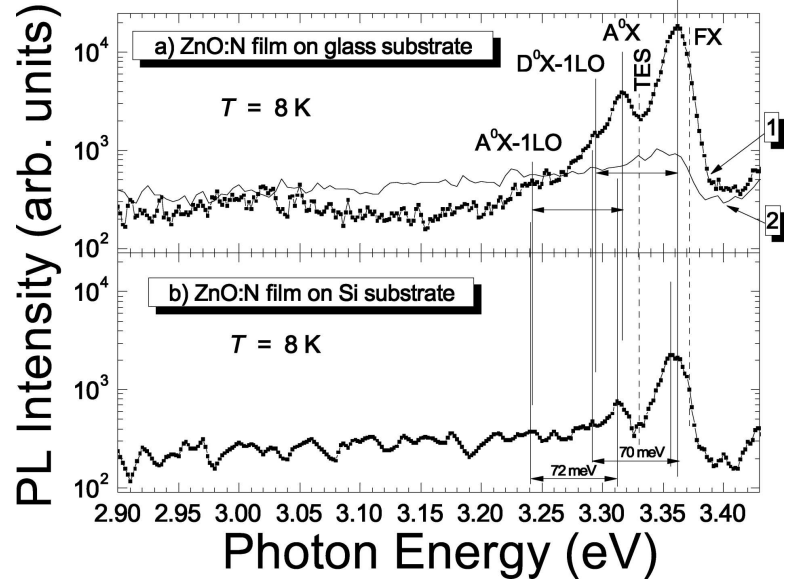

Fig. 12. Detailed view of the near-band-edge PL spectra of the $\mathrm{ZnO}: \mathrm{N}$ films at $8 \mathrm{~K}$. The spectral lines are denoted as follows: FX is a free exciton line at $3.372 \mathrm{eV} ; \mathrm{D}^{0} \mathrm{X}$ is a line of bound exciton related to neutral donor at $3.362 \mathrm{eV}$; TES marks two electron satellites at $3.330 \mathrm{eV} ; \mathrm{A}^{0} \mathrm{X}$ is a neutral acceptor related bound exciton line at 3.312-3.316 eV; 1LOs mark the first replicas of the longitudinal optical phonon assisted bound exciton recombination lines shifted by $70-72 \mathrm{meV}$ toward low energy side from $\mathrm{D}^{0} \mathrm{X}$ and $\mathrm{A}^{0} \mathrm{X}$ lines.

in Figs. 10 and 11 for ZnO:N films on glass and Si substrates, respectively.

The room temperature PL spectra consist of one predominant broad line at the near-band-edge spectral region with the peak energy of $3.23 \mathrm{eV}$ for both samples. The only minor difference is the full width at half maximum (FWHM) which is 259 and $274 \mathrm{meV}$ for $\mathrm{ZnO}: \mathrm{N}$ films on glass and Si substrates, respectively. The attention was concentrated on the near-band-edge spectral region of $\mathrm{ZnO}$ while the natural $\mathrm{ZnO}$ bands in yellowgreen spectral region were not measured specially.

The PL spectra were measured also from the other side of the sample plate in order to reveal the possible contribution of substrate. Such PL spectra are depicted in Figs. 10 and 11 as curve (c). It can be seen that the $\mathrm{ZnO}$ : $\mathrm{N}$ sample on glass substrate has some emission from substrate side in a given spectral range. It is a wide band with the FWHM of about $1.173 \mathrm{eV}$ and maximum at $3.255 \mathrm{eV}$, which is near to the peak position of $\mathrm{ZnO}: \mathrm{N}$ film PL spectrum. This could be the PL spectra of the film-substrate interface as the glass substrate is transparent for excitation wavelength. Such interface should be very disordered and this indicates a broadened PL band. Meanwhile, in the case of $\mathrm{ZnO}: \mathrm{N}$ film on $\mathrm{Si}$ substrate there is no noticeable radiation in the given spectral range when measuring from the backside of the sample.

The $\mathrm{ZnO}: \mathrm{N}$ film PL spectra at $8 \mathrm{~K}$ show two clearly 
resolved lines at 3.362 and $3.315 \mathrm{eV}$. The FWHM of the dominant line is 19.0 and $25.3 \mathrm{meV}$ for films on glass and Si substrates, respectively. This demonstrates rather poor quality of $\mathrm{ZnO}: \mathrm{N}$ films comparing, for example, to $3 \mathrm{meV}$ value of FWHM of MBE-grown $\mathrm{ZnO}$ epilayer on a sapphire substrate [25]. Detailed view of the low temperature PL spectra is illustrated in Fig. 12. The most intense two lines can be attributed to the radiative recombination of the bound excitons at neutral donors $\left(\mathrm{D}^{0} \mathrm{X}\right)$ and neutral acceptors $\left(\mathrm{A}^{0} \mathrm{X}\right)$. These two lines have LO phonon replicas shifted toward low energy side by $70-72 \mathrm{meV}$ with respect to the main lines. Weak free exciton emission (FX) can also be observed on the higher energy side of $\mathrm{D}^{0} \mathrm{X}$ line as a light shoulder at $3.372 \mathrm{eV}$. The line at $3.330 \mathrm{eV}$ is attributed to the two electron satellite (TES) transition. The excitation of neutral donor from initial state to excited 1s state during the radiative recombination of the donor bound exciton (also possible $2 \mathrm{~s}$ or $2 \mathrm{p}$ final states with the result of more adequate TES lines in PL spectra) is the mechanism behind this PL line. The dominant $\mathrm{D}^{0} \mathrm{X}$ line is a result of several overlapping PL lines [26]. We were able to resolve these lines at 3.362, 3.356, and $3.344 \mathrm{eV}$ by using the detection system with spectral resolution of less than $5 \mathrm{meV}$. All these lines are typical in the bulk $\mathrm{ZnO}$ single crystals and are attributed to the intrinsic shallow donors. The relatively weak FX line and intense $\mathrm{A}^{0} \mathrm{X}$ line evidence lower quality of the films and higher density of shallow acceptors in both $\mathrm{ZnO}: \mathrm{N}$ films in comparison with the bulk $\mathrm{ZnO}$ epilayers. The clearly pronounced $\mathrm{A}^{0} \mathrm{X}$ line is probably caused by nitrogen created states in $\mathrm{ZnO}$ matrix [27].

It also should be noted that PL signal from $\mathrm{ZnO}$ : N films was relatively weak when excitation beam was focused on the as-it-is sample surface. The PL signal increased nearly 20 times in magnitude (compare spectra 1 and 2 in Fig. 12(a)) when focused excitation beam was aimed at newly-cut area of sample surface. It gives an idea about strong surface recombination, which significantly depreciates the radiative properties of tested $\mathrm{ZnO}: \mathrm{N}$ samples.

\section{Conclusions}

$\mathrm{XRD}$ analysis of $\mathrm{ZnO}: \mathrm{N}$ thin films shows poor semiamorphous structure with broad peaks that can be attributed to the wurtzite-type $\mathrm{ZnO}$ structure. No peaks of $\mathrm{Zn}_{3} \mathrm{~N}_{2}$ were found for highly $\mathrm{N}_{2}$ doped films. Optical transmittance measurements and band gap determination revealed that the band gap decreases from 3.12 to $1.56 \mathrm{eV}$ upon lowering oxygen partial pressure during deposition from $2.2 \cdot 10^{-2}$ to $1.1 \cdot 10^{-2} \mathrm{~Pa}$. Highly $\mathrm{N}_{2}$ doped films have a small transparency for visible light, small resistivity $(0.61 \Omega \mathrm{cm})$, and negative coefficient of thermal resistance that is typical of semiconductors. The PL spectra revealed poor radiative properties and confirmed lower structural quality of $\mathrm{ZnO}: \mathrm{N}$ thin films. Low temperature PL spectra possess relatively intense $\mathrm{A}^{0} \mathrm{X}$ line at $3.314 \mathrm{eV}$ which is a signature of nitrogen caused shallow neutral acceptor states in $\mathrm{ZnO}$.

\section{Acknowledgements}

The authors would like to thank M. Lelys from Lithuanian Energy Institute for performing the XRD measurements and also T. Tamulevičius from Kaunas University of Technology for SEM imaging. The contribution of M. Karaliūnas and E. Kuokštis in this work was supported as a part of the Program on Mutual Funds for Scientific Co-Operation of Lithuania and Latvia with Taiwan.

\section{References}

[1] X.B. Wang, C. Song, D.M. Li, K.W. Geng, F. Zeng, and F. Pan, The influence of different doping elements on microstructure, piezoelectric coefficient and resistivity of sputtered ZnO film, Appl. Surf. Sci. 253, 1639-1643 (2006).

[2] J.F. Chang, H.H. Kuo, I.C. Leu, and M.H. Hon, The effects of thickness and operation temperature on $\mathrm{ZnO}: \mathrm{Al}$ thin film CO gas sensor, Sensors Actuators Chem. 84(2-3), 258-264 (2002).

[3] S. Flickyngerova, K. Shtereva, V. Stenova, D. Hasko, I. Novotny, V. Tvarozek, P. Sutta, and E. Vavrinsky, Structural and optical properties of sputtered $\mathrm{ZnO}$ thin films, Appl. Surf. Sci. 254, 3643-3647 (2008).

[4] E. Liu, P. Xiao, J.S. Chen, B.C. Lim, and L. Li, Ni doped $\mathrm{ZnO}$ thin films for diluted magnetic semiconductor materials, Curr. Appl. Phys. 8, 408-411 (2008).

[5] D.C. Look, and B. Claflin, P-type doping and devices based on ZnO, Phys. Status Solidi B 241(3), 624-630 (2004).

[6] D.C. Look, B. Claflin, Ya.I. Alivov, and S.J. Park, The future of $\mathrm{ZnO}$ light emitters, Phys. Status Solidi A 201(10), 2203-2212 (2004).

[7] N. Izyumskaya, V. Avrutin, Ü. Özgür, Ya.I. Alivov, and H. Morkoc, Preparation and properties of $\mathrm{ZnO}$ and devices, Phys. Status Solidi B 244(5), 1439-1450 (2007).

[8] M.D. McCluskey and S.J. Jokela, Defects in $\mathrm{ZnO}$, J. Appl. Phys. 106, 071101 (2009).

[9] J.F. Rommeluère, L. Svob, F. Jomard, J. MimilaArroyo, G. Amiri, A. Lusson, V. Sallet, O. Gorochov, P. Galtier, and Y. Marfaing, Nitrogen acceptors 
in $\mathrm{ZnO}$ films grown by metalorganic vapor phase epitaxy, Phys. Status Solidi C 1(4), 904-907 (2004).

[10] M. Futsuhara, K. Yoshioka, and O. Takai, Optical properties of zinc oxynitride thin films, Thin Solid Films 317, 322-325 (1998).

[11] W. Gao and Z. Li, ZnO thin films produced by magnetron sputtering, Ceram. Int. 30, 1155-1159 (2004).

[12] C. Wang, Z. Ji, J. Xi, J. Du, and Z. Ye, Fabrication and characteristics of the low-resistive $\mathrm{p}$-type $\mathrm{ZnO}$ thin films by DC reactive magnetron sputtering, Mater. Lett. 60, 912-914 (2006).

[13] M. Kawasaki, A key for realizing p-type $\mathrm{ZnO}$, in: CLEO/Pacific Rim Conference Proceedings: Lasers and Electro-Optics, 464-465 (2005).

[14] J.W. Sun, Y.M. Lu, Y.C. Liu, D.Z. Shen, Z.Z. Zhang, B.H. Li, J.Y. Zhang, B. Yao, D.X. Zhao, and X.W. Fan, The activation energy of the nitrogen acceptor in p-type $\mathrm{ZnO}$ film grown by plasma-assisted molecular beam epitaxy, Solid State Commun. 140, 345-348 (2006).

[15] D.C. Look, Electrical and optical properties of p-type ZnO, Semicond. Sci. Technol. 20, S55-S61 (2005).

[16] R.P. Howson, N. Danson, and I. Safi, High rate reactive sputtering using gas pulsing: a technique for the creation of films onto large, flat substrates, Thin Solid Films 351, 32-36 (1999).

[17] P.J. Kelly and R.D. Arnell, The determination of the current-voltage characteristics of a closed-field unbalanced magnetron sputtering system, Surf. Coatings Technol. 98, 1370-1376 (1998).

[18] P.J. Kelly and R.D. Arnell, Magnetron sputtering: a review of recent developments and applications, Vacuum 56, 159-172 (2000).
[19] M. Futsuhara, K. Yoshioka, and O. Takai, Structural, electrical and optical properties of zinc nitride thin films prepared by reactive rf magnetron sputtering, Thin Solid Films 322, 274-281 (1998).

[20] Springer Handbook of Electronic and Photonic Materials, eds. S. Kasap and P. Capper (Springer, 2006) pp. 57-62.

[21] A. Ashrafi, Heterointerfaces of stable and metastable ZnO phases, Appl. Surf. Sci. 255, 2342-2346 (2008).

[22] T. Sekiguchi, K. Haga, and K. Inaba, ZnO films grown under the oxygen-rich condition, J. Cryst. Growth 214(15), 68-71 (2000).

[23] T. Yang, Z. Zhang, Y. Li, M.S. Lv, S. Song, Z. Wu, J. Yan, and Sh. Han, Structural and optical properties of zinc nitride films prepared by rf magnetron sputtering, Appl. Surf. Sci. 255, 3544-3547 (2009).

[24] X.C. Wang, W.B. Mi, S. Dong, X.M. Chen, and B.H. Yang, Microstructure and optical properties of $\mathrm{N}$ incorporated polycrystalline $\mathrm{ZnO}$ films, J. Alloys Compounds 478(1-2), 507-512 (2009).

[25] Y. Chen, D. Bagnall, and T. Yao, ZnO as a novel material for the UV region, Mater. Sci. Eng. B 75, 190-198 $(2000)$

[26] B.K. Meyer, H. Alves, D.M. Hofmann, W. Kriegseis, D. Forster, F. Bertram, J. Christen, A. Hoffmann, M. Straßburg, M. Dworzak, U. Haboeck, and A.V. Rodina, Bound exciton and donor-acceptor pair recombinations in ZnO, Phys. Status Solidi B 241(2), 231-260 (2004).

[27] Ü. Özgür, Ya.I. Alivov, C. Liu, A. Teke, M.A. Reshchikov, S. Doğan, V. Avrutin, S.-J. Cho, and H. Morkoc, A comprehensive review of $\mathrm{ZnO}$ materials and devices, J. Appl. Phys. 98, 041301 (2005). 


\title{
ZnO:N PLĖVELIŲ SINTEZĖ REAKTYVIUOJU PASTOVIOS SROVĖS MAGNETRONINIU NUSODINIMU
}

\author{
S. Burinskas a ${ }^{\text {a }}$ J. Dudonis ${ }^{\text {a }}$, D. Milčius ${ }^{\text {a, b }}$, M. Karaliūnas ${ }^{\text {c }}$, E. Kuokštis ${ }^{c}$ \\ ${ }^{\text {a }}$ Kauno technologijos universiteto Fizikos katedra, Kaunas, Lietuva \\ ${ }^{\mathrm{b}}$ Lietuvos energetikos instituto Vandenilio energijos technologiju centras, Lietuva \\ ${ }^{\mathrm{c}}$ Vilniaus universiteto Puslaidininkiu fizikos katedra ir Taikomuju mokslu institutas, Vilnius, Lietuva
}

\section{Santrauka}

Cinko oksidas $(\mathrm{ZnO})$ laikomas viena iš perspektyvių medžiagų, siekiant sukurti $p-n$ vienalytès sandūros šviestukus, dèl plataus $(3,37 \mathrm{eV})$ draustinio energijų tarpo, santykinai pigių $\mathrm{ZnO}$ padèklų prieinamumo ir epitaksijos žemoje temperatūroje galimybės. Nors $n$ tipo priemaišu įterpimas i $\mathrm{ZnO}$ vyksta gana lengvai, iki šiol nerasta patikimo būdo įterpti $p$ tipo priemaišas. Perspektyviausiu akceptoriaus kandidatu beveik vieningai pripažistamas azotas, kadangi dèl labai panašaus joninio spindulio gali $\mathrm{ZnO}$ gardelèje lengvai pakeisti deguoni.

Cinko oksido su azoto priemaiša $(\mathrm{ZnO}: \mathrm{N})$ sintezei atlikti gali būti naudojama daugelis metodikų. Dažniausiai literatūroje yra sutinkami metalinis-organinis cheminis nusodinimas iš garų fazès, reaktyvinis garinimas impulsiniu lazeriu, radiodažnio arba nuolatinès srovès magnetroninis nusodinimas. Skirtingų autorių gautų $\mathrm{ZnO}: \mathrm{N}$ plèvelių savybės gana smarkiai skiriasi, galbūt dèl skirtingų formavimo technologiju bei naudojamų padèklų ívairovès. Patikimos informacijos stoka skatina atlikti papildomus $\mathrm{ZnO}: \mathrm{N}$ sintezès bei savybiụ tyrimus.

Šiame darbe $\mathrm{ZnO}: \mathrm{N}$ plèvelių nusodinimui buvo pasirinktas reaktyvusis nuolatinès srovès magnetroninis metodas, kadangi jis yra gana lengvai igyvendinamas, pasižymi gana dideliais nusodinimo greičiais ir leidžia plačiame intervale keisti junginio stechiometrija. Pagrindinis tokio metodo panaudojimo sunkumas - sudètinga reaktyviụjų dujų dalinio slègio ir tuo pačiu sudaromo junginio stechiometrijos priklausomybė nuo ịvairių technologinių parametrų.

Nusodintų plèvelių morfologija buvo ištirta rastriniu elektroni- niu mikroskopu FEI Quanta 200F. Kristalinei struktūrai nustatyti buvo panaudotas Rentgeno difraktometras Bruker AXS D8 Advance su monochromatine $\mathrm{Cu} \mathrm{K}$ spinduliuote. Elektrinès savybès išmatuotos dviejų zondų metodu. Optinis plèvelių skaidris buvo išmatuotas UV-VIS spektrofotometru Spectronic GENESYS 8. Fotoliuminsecencijos tyrimai buvo atlikti kambario ir $8 \mathrm{~K}$ temperatūroje, žadinant nanosekundinio YAG:Nd lazerio 4-os harmonikos spinduliuote.

Tyrimų rezultatai rodo i̇vykusị azoto įmaišymą i ZnO. Rentgeno spinduliu difrakcijos analizė parodė prastos kokybės pusiau amorfinę kristalinę ZnO:N plèvelių struktūrą. Plačios Rentgeno difrakcijos spektrų linijos priskirtinos heksagoninės struktūros $\mathrm{ZnO}$, o bandiniuose su dideliu $\mathrm{N}_{2}$ kiekiu $\mathrm{Zn}_{3} \mathrm{~N}_{2}$ priskiriamų smailių neaptikta. Optinio skaidrumo matavimai ir draustinio energijos tarpo nustatymas patvirtino draustinio tarpo mažèjimą nuo $3,12 \mathrm{iki} 1,56 \mathrm{eV}$, mažinant deguonies dalini slègi auginimo metu nuo $2,2 \cdot 10^{-2}$ iki $1,1 \cdot 10^{-2} \mathrm{~Pa}$. Daug $\mathrm{N}_{2}$ turinčios plèvelès yra mažai skaidrios regimai šviesai, turi mažą elektrinę varžą $(0,61 \Omega \mathrm{cm})$ ir pasižymi neigiamu šiluminès varžos koeficientu, būdingu puslaidininkiams. Fotoliuminescencijos (FL) spektrų matavimai parodè menkas plèvelių spindulines savybes ir patvirtino prastą $\mathrm{ZnO}: \mathrm{N}$ plẻvelių struktūros kokybę. Žemos temperatūros fotoliuminescencijos spektrai yra būdingi $\mathrm{ZnO}$ epitaksiniams sluoksniams su dominuojančia $\mathrm{D}^{0} \mathrm{X}$ spektrine linija, tačiau pasižymi santykinai intensyvia $\mathrm{A}^{0} \mathrm{X}$ linija ties $3,314 \mathrm{eV}$, kuri priskiriama azoto sukurtoms seklioms akceptorinėms priemaišoms cinko okside. 